Article

\title{
The Wily and Courageous Red Fox: Behavioural Analysis of a Mesopredator at Resource Points Shared by an Apex Predator
}

\author{
Eamonn Wooster *, Arian D. Wallach and Daniel Ramp \\ Centre for Compassionate Conservation, University of Technology Sydney, P.O. Box 123, Ultimo, New South \\ Wales 2007, Australia; Arian.Wallach@uts.edu.au (A.D.W.); Daniel.Ramp@uts.edu.au (D.R.) \\ * Correspondence: Eamonn.Wooster@uts.edu.au
}

Received: 21 September 2019; Accepted: 31 October 2019; Published: 4 November 2019

check for updates

Simple Summary: The red fox is one of the Earth's most widespread mammalian predators. Human globalisation has further expanded its range, so that today they are found on most continents. Despite their abundance, knowledge of fox behaviour remains limited. Most studies have observed foxes either in captivity or in their native range where both they and their predators are killed by humans. We conducted a behavioural study on foxes outside of their native range in Australia, at a unique location where all wildlife are protected. We developed an ethogram to explore fox behaviour at resource points shared with a potentially deadly apex predator, the dingo. We were surprised to find that foxes were in a confident state more often than in a cautious state, even leaving territorial markings over those of dingoes. One possible explanation for the confidence of foxes is that the social stability of both foxes and dingoes makes their world more predictable.

\begin{abstract}
The red fox (Vulpes vulpes) is a widespread and ecologically significant terrestrial mesopredator, that has expanded its range with human globalisation. Despite this, we know relatively little about their behaviour under the wide range of ecological conditions they experience, particularly how they navigate the risk of encounters with apex predators. We conducted the first ethological study of foxes outside their historic native range, in Australia, where both the foxes and their main predator were protected from human hunting. Using remote camera traps, we recorded foxes visiting key resource points regularly utilised by territorial dingoes (Canis dingo), their local apex predator, in the Painted Desert, South Australia. We constructed an ethogram sensitive to a range of behaviours and attitudes. Since foxes are suppressed by dingoes, we expected that the foxes would primarily be in a cautious state. In contrast, we found that foxes were in a confident state most of the time. Where human hunting is absent, social stability of predators may increase predictability and therefore decrease fear.
\end{abstract}

Keywords: Vulpes vulpes; Canis dingo; landscape of fear; trophic cascades; mesopredator

\section{Introduction}

"Look at him. His coat is russet with sufficient gold in it to make him glow. He has just enough of a ruff to please a very young lion and enough tail to be the pleasure of any animal that grows a tail. His snout is a bit pinched-looking and would be mean if there wasn't so much pride in his carriage-he walks the Australian earth as though it was a carpet especially laid for him". (Rolls 1969)

The red fox (Vulpes vulpes) is one of the most widespread of all carnivores, having populations on all continents except Antarctica and South America [1]. They inhabit a wide range of habitats, including tundras, temperate woodlands, coasts, and deserts. Foxes have adapted to, and benefited from, the 
ecological changes of the Anthropocene, exploiting anthropogenic resources [2] and experiencing release from predation through the extirpation of apex predators in both urban and agricultural landscapes [3]. Foxes have also significantly expanded their historic range through introductions by humans, establishing populations in nine new countries over the last 170 years [4]. Studying the behaviour of animals outside of their historical ranges provides a unique opportunity to explore how species and individuals adapt to the challenges and opportunities of new environments.

One population that has flourished due to human-assisted migration is in Australia. Foxes were first introduced to Australia in the 1830s, brought to Victoria for hunting. Within a century they had expanded their range throughout much of the continent [5]. Bounty programs and "pest" status were first established in the 1890s, both of which continue today. Foxes are routinely shot, poisoned, trapped, and gassed, everywhere from national parks to farms and urban parklands. These lethal programs exist alongside a similar campaign against dingoes (Canis dingo), Australia's only remaining mammalian apex predator. This has left foxes in a state of "mesopredator release", removed from top-down pressure [6]. Hence, although foxes are heavily targeted by control programs, these efforts have not led to local or functional extirpation.

Apex predators limit the densities and spatial distribution of smaller predators, through competition, predation, and intraguild competitive killing [7]. The ecology and behaviour of foxes, in both their historic and introduced ranges is actively shaped by predation and interference by apex predators $[3,8]$. Within their historic native range, foxes are suppressed by coyotes in North America (Canis latrans) [9] and wolves in Europe (Canis lupus) [10], while in Australia they are suppressed by dingoes [11]. In response to the presence of apex predators, foxes are known to alter spatio-temporal activity patterns and increase vigilance behaviour, helping them to detect and avoid risky encounters [12,13]. This creates a "landscape of fear", represented by "peaks" (high risk) and "valleys" (low risk) [14]. In North America, foxes have been shown to exploit urban areas to avoid coyotes [9], while in the Australian desert, foxes avoid water sources where dingo activity is concentrated [15].

A review of ethological studies revealed that most research on wild foxes has occurred where apex predators were absent $(80 \%)$ and where foxes and their predators were subjected to lethal control $(83 \%)$ (Table 1). Only two studies were conducted where both foxes and their predators were protected $[12,16]$, both within the fox's historic range. A further eight studies were conducted in the wild that did not report whether apex predators were present, protected, or killed; three studies were conducted in captivity; while the rest were conducted without apex predators present. To the best of our knowledge, no study has been concerned solely with understanding fox behaviour outside their historic range. Although there has been much research on foxes in Australia, most of it has been concerned with how to suppress their populations $[17,18]$. Our interest, therefore, was in developing a suitable ethogram of fox behaviour and then implementing that ethogram to study wild fox behaviour in an introduced setting without interference from human persecution of themselves or of their predators. To do this, we made use of a rare 'predator friendly' landscape in the Australian desert to observe fox behaviour where they are at risk from potentially deadly encounters with dingoes. Due to the high level of risk dingoes can pose to foxes, we expected that foxes would be highly cautious when accessing resource points shared with territorial dingoes. 
Table 1. Review of fox behaviour literature highlights the most common ecological contexts foxes are studied under.

\begin{tabular}{|c|c|c|c|c|c|}
\hline Behavioural Study & Country & Wild/Captive & Foxes Killed & Apex Predators & References \\
\hline \multirow{6}{*}{$\begin{array}{l}\text { Anti-predator } \\
\text { behaviour }\end{array}$} & Australia & Wild & Yes & Dingo (Canis dingo) & [19] \\
\hline & Canada & Wild & Unstated & Coyote (C.latrans) & [20] \\
\hline & Croatia & Wild & No & Wolf (C.lupus) & [16] \\
\hline & Israel & Wild & No & $\begin{array}{l}\text { Golden jackal } \\
\quad(\text { C.aureus })\end{array}$ & [12] \\
\hline & North America & Wild & Unstated & Coyote & [9] \\
\hline & Poland & Wild & Unstated & Lynx $(\operatorname{Lyn} x \operatorname{lyn} x)$ & [13] \\
\hline \multirow{4}{*}{$\begin{array}{l}\text { Fox kit ethogram } \\
\text { Reproduction } \\
\text { Sociality }\end{array}$} & Switzerland & Wild & Unstated & Unstated & [21] \\
\hline & North America & Wild & Yes & Unstated & [22] \\
\hline & England & Wild & Yes & No & [23] \\
\hline & England & Captive & N/A & N/A & [24] \\
\hline \multirow{3}{*}{ Scent marking } & North America & Captive & N/A & N/A & [25] \\
\hline & Canada & Wild & Unstated & Unstated & [26] \\
\hline & $\begin{array}{l}\text { Israel \& North } \\
\text { America }\end{array}$ & Both & Unstated & Unstated & [27] \\
\hline \multirow{9}{*}{$\begin{array}{l}\text { Spatiotemporal } \\
\text { patterns }\end{array}$} & Spain & Wild & Unstated & Unstated & [28] \\
\hline & England & Wild & Yes & No & [29] \\
\hline & England & Wild & Yes & No & [30] \\
\hline & England & Wild & Yes & No & [31] \\
\hline & England & Wild & Yes & No & [32] \\
\hline & Italy & Wild & Yes & No & [33] \\
\hline & Italy & Wild & Yes & Unstated & [34] \\
\hline & Italy & Wild & Yes & Unstated & [35] \\
\hline & Japan & Wild & Yes & Unstated & [36] \\
\hline \multirow{2}{*}{ Feeding behaviours } & Switzerland & Captive & N/A & N/A & [37] \\
\hline & Sweden & Wild & Unstated & Unstated & [38] \\
\hline
\end{tabular}

Data gathered for this review comes from a Web of Science search, using "red fox behaviour" as the search term, refined for "behavioural sciences". Reference trails were also included in the review. Unstated was noted if authors did not mention whether the variable in question was present during their study. N/A refers to a variable not being applicable to the study (e.g., Foxes killed is not relevant to a study conducted in captivity).

\section{Materials and Methods}

\subsection{Study Sites}

Our study was conducted across two contiguous predator friendly properties in the Painted Desert, South Australia. The properties include a $2300 \mathrm{~km}^{2}$ cattle station and a $5600 \mathrm{~km}^{2}$ Indigenous Protected Area, utilised in part for cattle and horse grazing. Foxes are likely to have been resident in the area as early as 1940, by which point they were already present in over two-thirds of Australia [39]. The landscape is arid, with average rainfall around $160 \mathrm{~mm}$ annually, and is dominated by chenopod shrublands, tall Acacia woodland, and Eucalyptus species along ephemeral creeks. Reliable sources of drinking water were limited to semi-permanent rain-filled dams and permanent bores spread evenly across the landscape, approximately every $10 \mathrm{~km}$. Historically, predators had been regularly poisoned, shot, and trapped across the region, but non-lethal predator friendly practices were established on both properties by 2012 [40].

\subsection{Recording Fox Behaviour}

We remotely filmed foxes at water sources, rabbit warrens, and large carcasses; resource points known to be utilised by territorial foxes and dingoes [41]. Predators are highly elusive and thus, behavioural data is difficult to obtain as direct observations are not possible. This makes camera trapping the only source of gathering such data. Camera traps were placed at water points approximately $10 \mathrm{~km}$ apart, however, rabbit warrens and carcasses were usually located within $3 \mathrm{~km}$ of the water points. As we were unable to identify individual foxes, and foxes home ranges vary between $8-33 \mathrm{~km}^{2}$ in arid environments [42], we caution that it is possible that we observed the same individuals across multiple resource points. Water sources in the arid zone are important resources for predators; for 
drinking, socialising, communicating, and hunting $[15,43]$. The highest concentration of dingo scent marking occurs at arid zone water sources, with some waters having over 100 dingo scats. Dingo scent marking concentrates in areas where they are socially stable [40]. Scent marking is an indicator of social stability in canids as it is a common method of communicating sociality and territoriality. Large carcasses are important as resource points for food and as focal points for scent marking for both foxes and dingoes [41]. Foxes readily scavenge carcasses of large prey killed by apex predators [44], and both foxes and dingoes scavenge domestic animals discarded by humans [45]. Both predators are also significant predators of rabbits (Oryctolagus cuniculus) [45,46] and use rabbit warrens to locate prey and for scent marking [28,41]. Rabbits warrens are burrows dug and utilised by rabbits for shelter and raising young, they are identified through tracks or scats present at their entrance. We focused this study on resource points as they are both essential parts of life within the desert for both foxes and dingoes and as they represent potential points of conflict between them.

We monitored fox behaviour through 3 winters (June-July; 2016-2018). In 2016, we monitored 10 water points; in 2017, we monitored 18 water points (of which eight were also monitored in 2016), 17 rabbit warrens, and five carcasses; and in 2018 we monitored 10 water points (of which six were also monitored in 2017, and three were monitored over all three years), eight rabbit warrens, and four carcasses (two of which were monitored for three years). We strapped camera traps (Bushnell MKII and Browning Dark Ops Pro) to trees and posts at 30-60 cm high for 1-3 weeks set to record time-stamped 15-20 s videos, with one second delays. Cameras were hidden to the best of our ability to reduce the chance of behavioural responses being influence by the camera traps themselves. Cameras were active $24 \mathrm{~h}$ a day and were checked at least once a week. We set up to three cameras per water source, up to two cameras per rabbit warren, and up to two cameras per carcass, with the number varying based on the size of each resource point. We treated points independently for temporal analysis, if foxes were present on more than one camera at a single resource point within $30 \mathrm{~min}$ of each other, we considered them part of the same activity event [47].

\subsection{Construction of a Fox Ethogram}

We identified and described discrete fox behaviours to create an ethogram sensitive to wariness of foxes to predation while accessing resource points. We characterised fox behaviours from literature in ethology [25,48-50], animal personality [51], and animal welfare [52], and from assessments made by captive fox carers (Sydney Fox Rescue). The ethogram was first organised into base behaviours, describing key actions such as locomotion and foraging (Table 2). Base behaviours were classified as either state events or point events for purposes of measurement. State events were defined as continuous behaviours (e.g., locomotion) and were measured in units of time ( $>1 \mathrm{sec}$ ), while point events were defined as instantaneous behaviours (e.g., startled jump) and were measured in units of frequency $(<1 \mathrm{sec})$. All base behaviours were further refined through modifiers, which were descriptive terms used to contextualise base behaviours both physically and mentally [53]. For example, 'locomotion' was modified by a range of both physical states, such as walking, running, jumping, or perching, and by attitudinal states, such as whether the actions were engaged in confidently or cautiously. Attitudinally modified behaviours were classified as either confident or cautious based on the foxes' body position. Cautious behaviour is primarily categorised by the tail positioned below the height of the back, the torso positioned close to the ground, and the legs spread apart. Cautious behaviour shares body positions with vigilant behaviour. In contrast, confident behaviours were primarily classified where the foxes are observed with the tail held above or level to the back, legs are extended and positioned close together (Figure 1, Table 3, Supplementary Material Table S1).

Behavioural analysis of videos was performed using the behavioural analysis software BORIS version 4.1.4 [53]. We analysed observed behaviours for duration and/or frequency, according to the definitions in our ethogram. We calculated the proportion of time each base behaviour and modifier combination contributed to the total time of fox behaviour. Point events were analysed exclusively for their frequency of occurrence. Where more than one fox was present, behaviour was analysed 
separately. We tested for differences in the proportion of time allocated to each base behaviour between the surveyed resource points, and for differences in the proportion of confident and cautious behaviour within and between each resource point, using separate negative binomial regressions, one per behaviour (link function: log). All proportions were modelled as integers. In each regression, we set the proportion of time allocated in a given behaviour as the response variable. We included resource type as the predictor variable. We tested significance of the predictor using a Tukey post hoc test in $\mathrm{R}$ version 3.4.1 using the package emmeans [54]. Behaviours with only one attitudinal modifier (e.g., vigilance and scent marking) were removed from this analysis. Digging was also left out as it was only observed once. Negative binomial regressions were performed through the $\mathrm{R}$ version 3.4 .1 using the package MASS [54].

We analysed fox activity patterns at each of the three resource points (i.e., water sources, rabbit warrens, and carcasses). Temporal activity patterns were compared using kernel densities, to estimate activity overlap between the resource points by calculating the area under the curve where all three temporal patterns overlapped. We did this by calculating the densities at which each temporal pattern intersected and then integrated the area where all resource points overlapped, compared to the total curve area. Finally, we recorded the frequency foxes were observed alone or in company. All analyses were performed in $\mathrm{R}$ version 3.4.1 [54].

Table 2. Ethogram for foxes at resource points. Modifiers further describe the behaviour observed.

\begin{tabular}{|c|c|c|}
\hline Behaviour State & Modifiers & Definition \\
\hline Locomotion (S) & $\begin{array}{l}\text { A) Walk/Run/Jump/Perch } \\
\text { B) Cautious/Confident }\end{array}$ & All spatial movements \\
\hline Sniffing (S) & Cautious/Confident & $\begin{array}{c}\text { Exploring area of interest leading with the } \\
\text { nose, the head moves up and down with neck } \\
\text { extended }\end{array}$ \\
\hline Digging (S) & Cautious/Confident & $\begin{array}{l}\text { Investigation of ground utilising the front two } \\
\text { paws to remove a layer of soil }\end{array}$ \\
\hline Vigilance (S) & Low/High & $\begin{array}{l}\text { Examination of the surrounding environment } \\
\text { in a state of alert or heightened awareness, } \\
\text { the head moves directionally, head is moving } \\
\text { rapidly or focused on an object or location. } \\
\text { Individuals are positioned low to the ground } \\
\text { with legs splayed (see Figure 1D) }\end{array}$ \\
\hline Foraging $(S)$ & A) Scavenging/Drinking/Hunting & $\begin{array}{l}\text { The act of feeding on carrion, ingesting water } \\
\text { from a natural or anthropogenic water source } \\
\text { or hunting for prey }\end{array}$ \\
\hline & $\begin{array}{c}\text { B) Cautious/Confident } \\
\text { C) Alone/Social }\end{array}$ & \\
\hline Scent marking (S) & A) Defecation/Raking/Rubbing & $\begin{array}{l}\text { The raising of a hind leg or leaning into a } \\
\text { squat position in order to deposit urine or } \\
\text { scats onto a point of interest, using a paw to } \\
\text { rake the ground or the act of rubbing face, } \\
\text { paw or tail glands on an object }\end{array}$ \\
\hline Flight $(\mathrm{P})$ & $\begin{array}{c}\text { B) Alone/Social } \\
\text { Startled Jump/Startled Flee }\end{array}$ & $\begin{array}{c}\text { Dramatic and exaggerated responses to } \\
\text { environmental or camera born stimuli. Body } \\
\text { movements are rapid, legs, torso and head } \\
\text { perform sudden and reckless movements to } \\
\text { jump or flee away from the location where } \\
\text { they were startled }\end{array}$ \\
\hline Investigating (S) & Cautious/Confident & $\begin{array}{l}\text { The act of surveying the environment. } \\
\text { Head moves directionally, can be performed } \\
\text { stationary or during locomotion }\end{array}$ \\
\hline Frustration $(\mathrm{P})$ & & $\begin{array}{c}\text { An outburst of frustration manifested by } \\
\text { biting or gnawing on an object in the } \\
\text { environment }\end{array}$ \\
\hline Head shake $(\mathrm{P})$ & & $\begin{array}{l}\text { A rapid shaking of the head in an attempt to } \\
\text { remove or dislodge an item of irritation }\end{array}$ \\
\hline
\end{tabular}


Table 2. Cont.

\begin{tabular}{|c|c|c|}
\hline Behaviour State & Modifiers & Definition \\
\hline Salivating $(\mathrm{P})$ & & $\begin{array}{l}\text { A display of hunger at the anticipation of } \\
\text { food involving the licking of the outside of } \\
\text { an individual's mouth }\end{array}$ \\
\hline Resting (S) & & $\begin{array}{l}\text { An absence of discernible activity. An } \\
\text { individual laying on the ground with all four } \\
\text { legs relaxed or sitting down on back end with } \\
\text { front paws fully extended, supporting the } \\
\text { individual. Individual is motionless. Head } \\
\text { may be focused on the ground, sky or on } \\
\text { nothing in particular but is motionless }\end{array}$ \\
\hline Greeting (S) & Facial/Posterior/Denial & $\begin{array}{l}\text { The act of sniffing a conspecific to identify and } \\
\text { communicate with the individual }\end{array}$ \\
\hline Play (S) & Jump/Chase & $\begin{array}{c}\text { One individual actively solicits a non-agonistic } \\
\text { interaction, with random and exaggerated } \\
\text { movements }\end{array}$ \\
\hline
\end{tabular}

Point events describe instantaneous behaviours (P). State events describe continuous behaviour (S).

\section{Results}

We identified 14 base behaviours useful for categorising activity around resource points: locomotion, sniffing, digging, vigilance, foraging, flight, investigating, frustration, salivating, head shake, play, greeting, and resting (Table 2, Figure 1). We also identified five modifiers for those behaviours: type (e.g., locomotion modified as walking or running), attitudinal (e.g., locomotion modified as cautious or confident), intensity (e.g., vigilance modified as high or low), and social (e.g., foraging modified as social or alone) (Table 3).

We gathered a total of $55.33 \mathrm{~min}$ of fox footage (1.33 min from 2016, $42 \mathrm{~min}$ from 2017, and $12 \mathrm{~min}$ from 2018). Dingoes were present at all resource points surveyed, with evidence of scent marking by dingoes recorded at all carcasses, at $97 \%$ of water points, and at $47 \%$ of rabbit warrens. While accessing resource points, foxes spent most of their time engaged in the relevant foraging behaviour associated with that resource (e.g., scavenging at carcasses, and drinking at water points), as well as sniffing and locomoting (Figure 2). There were no major differences in behavioural activity between the three resource types. On average, foxes spent $12 \mathrm{~s}$ on camera, with the longest recorded at $65 \mathrm{~s}$.

The average proportion of time allocated to a behavioural state was independent of the attitude of the fox (i.e., the time did not change whether the behaviour was done confidently or cautiously) (Figure 2). Similar trends were detected across resource points, although at carcasses, foxes spent a significantly higher amount of time on average in cautious locomotion than confident locomotion ( $p=$ 0.02) (Figure 2). Foxes foraging at rabbit warrens (i.e., hunting) were always observed in a confident state. Scent marking was also observed exclusively confidently. Overall, foxes were more likely to be detected in a confident, rather than cautious, behavioural state. Confident states at carcasses were engaged in more frequently while investigating (23 times more often), sniffing (8.5 times), locomoting (7.5), and foraging (5.5 times), while confident foraging was engaged in more frequently than cautious foraging at water sources (6.6 times) (Table 4).

Scent marking was most common at carcasses with a rate of one scent mark every $88.5 \mathrm{~s}$, followed by water points at one scent mark every $92.6 \mathrm{~s}$. Scent marking was observed much less frequently at rabbit warrens, with only one scent mark every 9.3 min. Fox scent marking comprised of scat deposition and urination $(n=32)$, raking $(n=1)$, and rubbing $(n=1)$.

Foxes primarily accessed resource points between dusk and dawn (06:00 and 18:00), but they visited each at slightly different times throughout the night, overlapping at 56\% (Figure 3). Fox activity at carcasses was concentrated at two peaks, in the early morning (00:00-03:00) and evening (18:00-22:00). Similarly, activity at water sources was most frequent between 03:00 and 06:00 as well as 20:00 and 23:00. Rabbit warren activity was concentrated into a single peak in the evening (19:00-22:00). 
Fox social behaviour comprised of two pairs at two carcasses, lasting in total for 5.10 minutes. Fox pairs spent the highest average proportion of their time sniffing (43\%), followed by locomotion $(33 \%)$ and foraging $(27 \%)$. During this time, they played $(n=6)$, greeted one another $(n=5)$, and scent marked $(n=4)$.

\section{A}

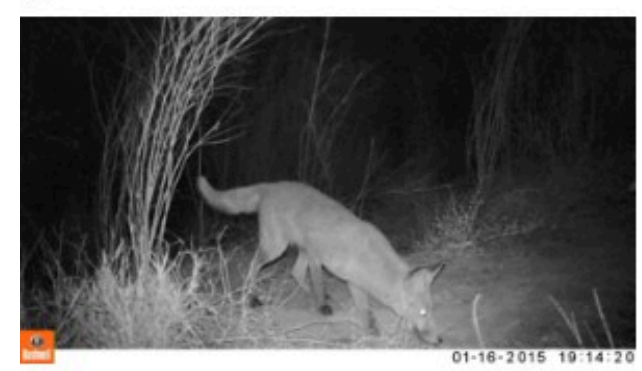

C

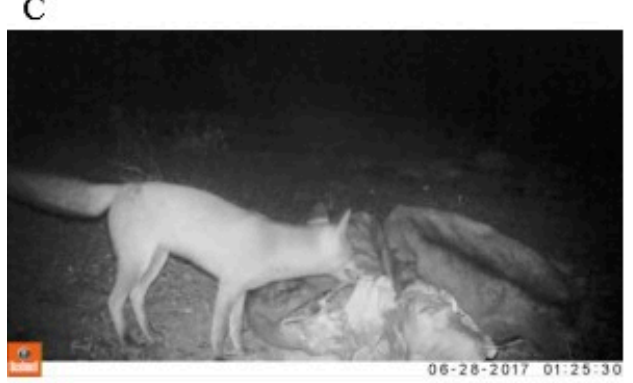

E

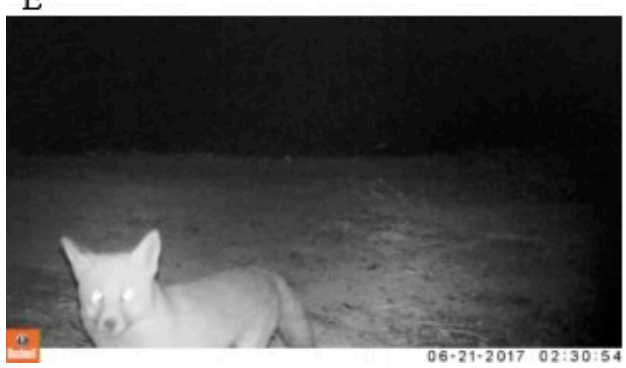

B

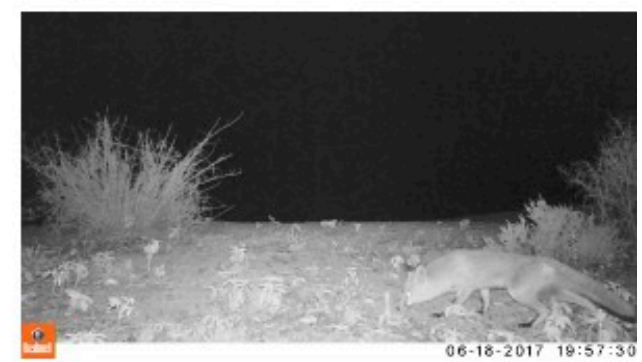

$\mathrm{D}$

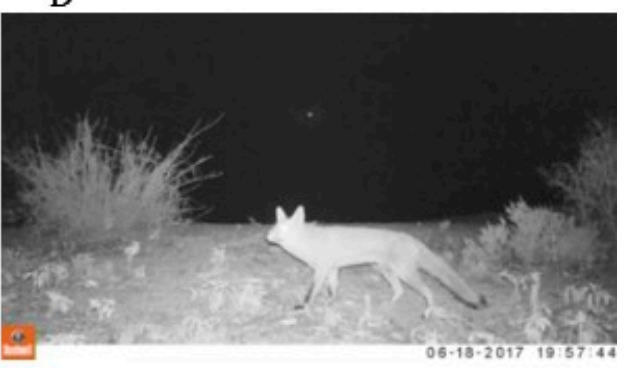

F

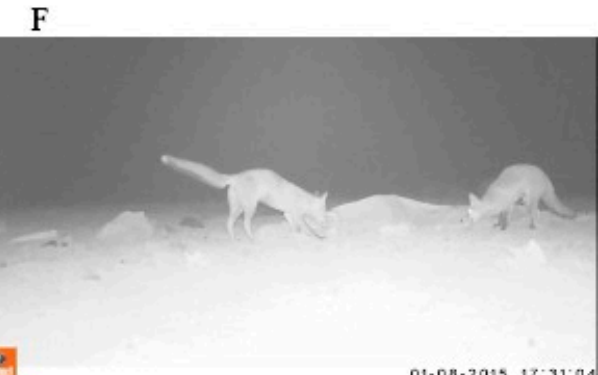

Figure 1. Behaviours observed in this study and used to classify fox behaviour: (A) confident sniffing and walking, (B) cautious sniffing and walking, (C) confident scavenging, (D) high vigilance, (E) cautious camera investigation, (F) social foraging. See supplementary material 1 for an example of behaviourally scored video.

Table 3. Descriptions of some red fox ethogram modifiers.

\begin{tabular}{|c|c|c|}
\hline Behaviour & Modifiers & Description \\
\hline Locomotion & B) Attitudinal & $\begin{array}{l}\text { Walk: Slow quadrupedal movement } \\
\text { Run: Fast quadrupedal movement } \\
\text { Jump: Vertical or horizontal jump } \\
\text { Perch: The lifting of two paws onto an object in order to investigate } \\
\text { a resource or object of interest } \\
\text { Confident: Head not focused on anything in particular, head } \\
\text { movements are relaxed, ears are relaxed and kept vertical (unless } \\
\text { sound is heard, if so, ears will move directionally), little concern } \\
\text { over movement. Tail held high, parallel to the ground, level with } \\
\text { the back, may have a kink towards the end pointing upwards } \\
\text { Cautious: Head moves erratically, ears pricked forward, cautious } \\
\text { paw placement with back feet placed firmly with movement only } \\
\text { occurring in front feet, stands with legs close together and bent. } \\
\text { Tail positioned closer to the back legs, lower than level with the } \\
\text { back, with no kink, shoulders are raised }\end{array}$ \\
\hline
\end{tabular}


Table 3. Cont

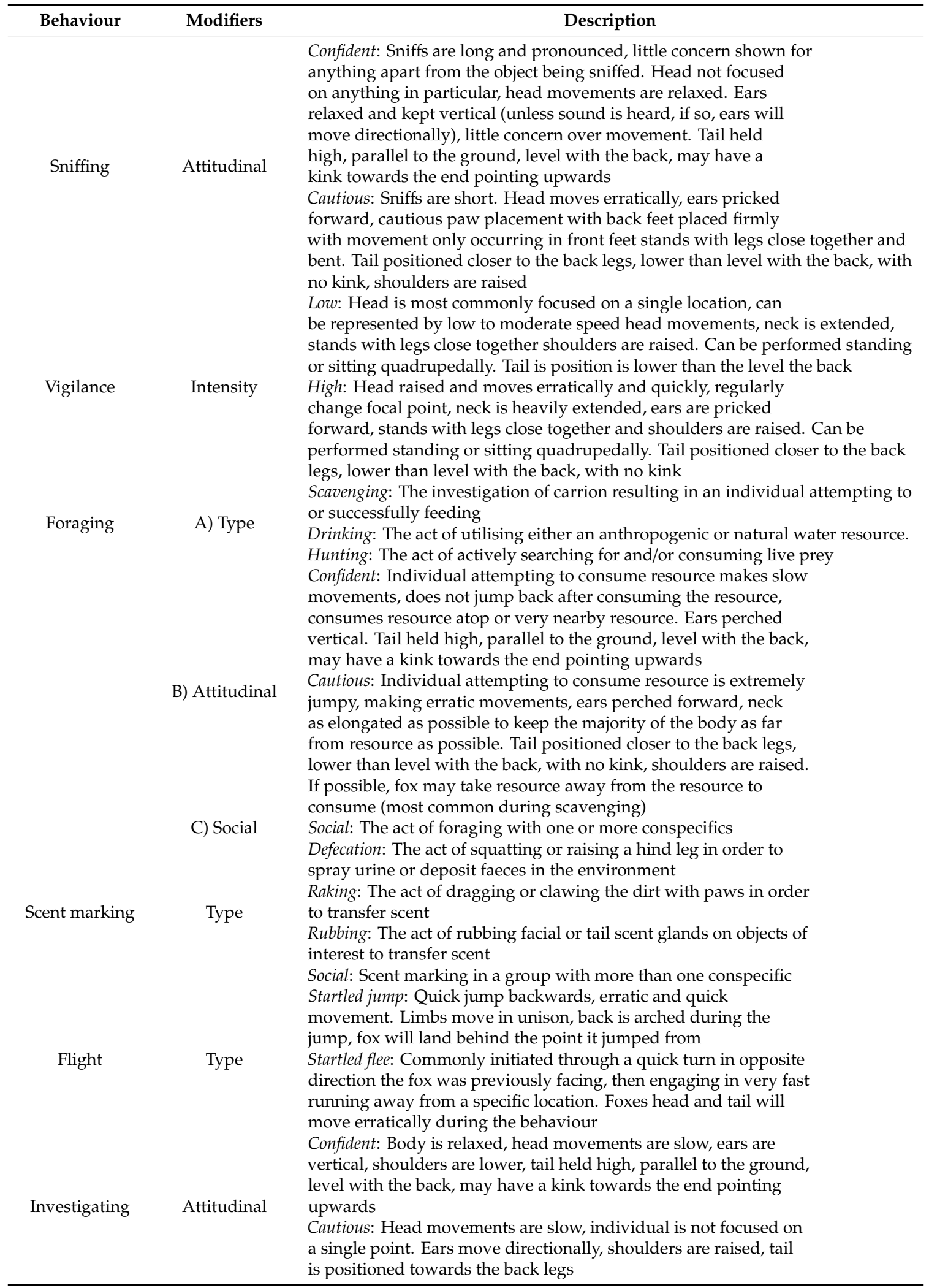


Table 3. Cont

\begin{tabular}{|c|c|c|}
\hline Behaviour & Modifiers & Description \\
\hline & & $\begin{array}{l}\text { Facial: The act of sniffing the face and/or glands of the face of a } \\
\text { conspecific }\end{array}$ \\
\hline Greeting & Type & $\begin{array}{l}\text { Posterior: The act of sniffing the anus, anal glands or genitals of a } \\
\text { conspecific }\end{array}$ \\
\hline & & $\begin{array}{l}\text { Denial: The movement or jumping away from a conspecific after } \\
\text { an attempted greeting }\end{array}$ \\
\hline & & $\begin{array}{l}\text { Jump: Leaping towards or away from a conspecific in a } \\
\text { non-agonistic manner, with random and exaggerated movements }\end{array}$ \\
\hline Play & Type & $\begin{array}{l}\text { Chase: The running or walking after or away from a conspecific } \\
\text { in a non-agonistic manner, with random and exaggerated } \\
\text { movements }\end{array}$ \\
\hline
\end{tabular}

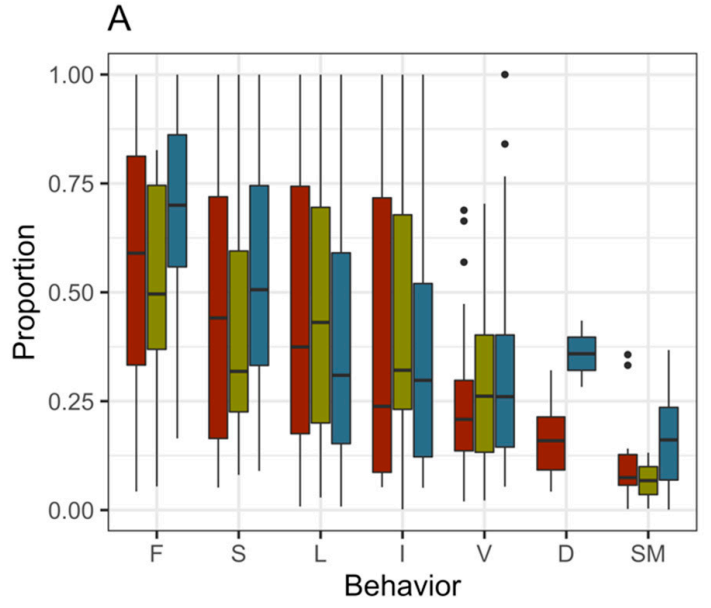

Resource Carcass 追 Warren 불

C

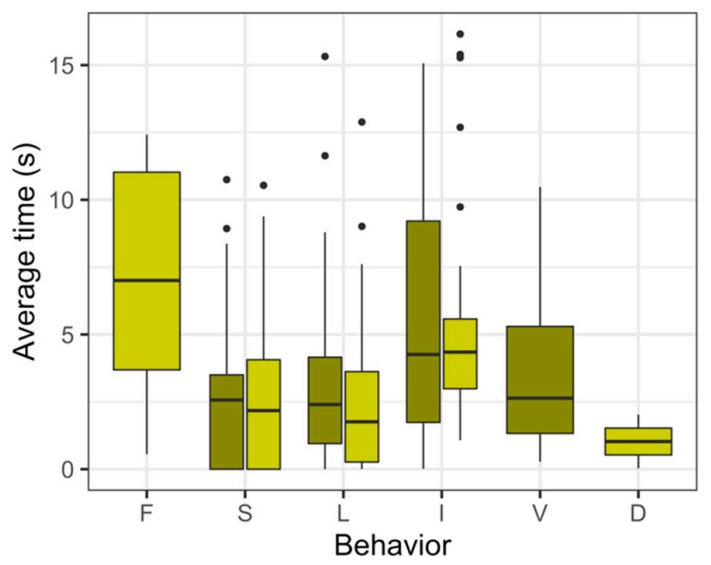

Attitude 官 Cautious 官 Confident

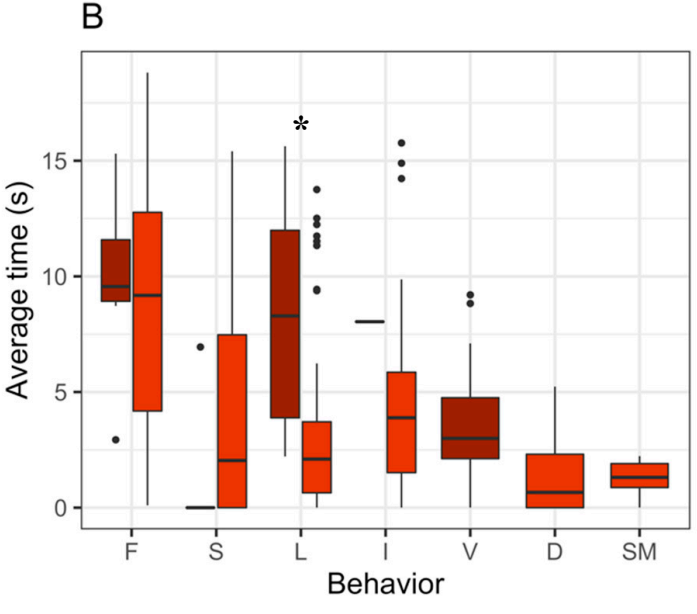

Attitude Cautious Confident

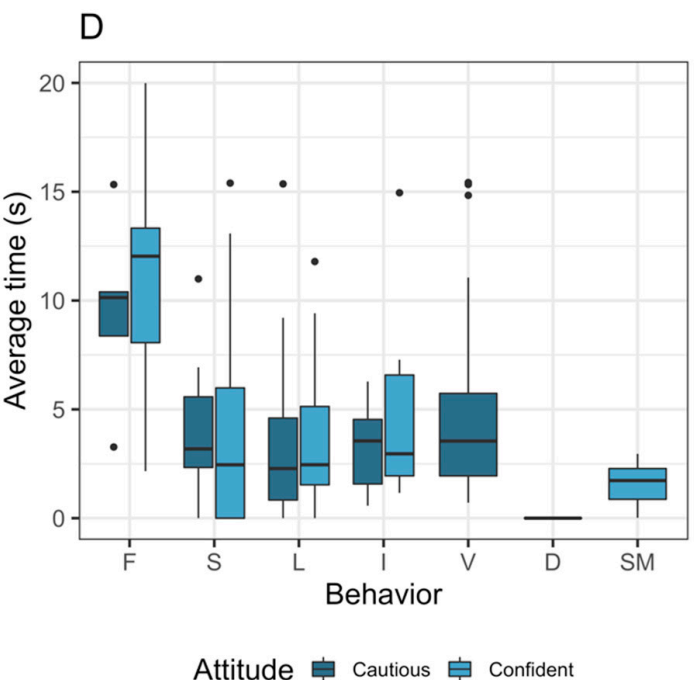

Figure 2. Confidence and cautiousness of red foxes at key resource points share with dingoes. Proportion of time allocated to each behaviour at each resource type (A). The average amount of time allocated to confident and cautious behaviours at carcasses (B), rabbit warrens (C), and water points (D). F = foraging, $\mathrm{S}=$ sniffing, $\mathrm{L}=$ locomotion, $\mathrm{I}=$ investigating, $\mathrm{V}=$ vigilance, $\mathrm{D}=$ digging, $\mathrm{SM}=$ scent marking. Statistical significance indicated by an asterisk. 


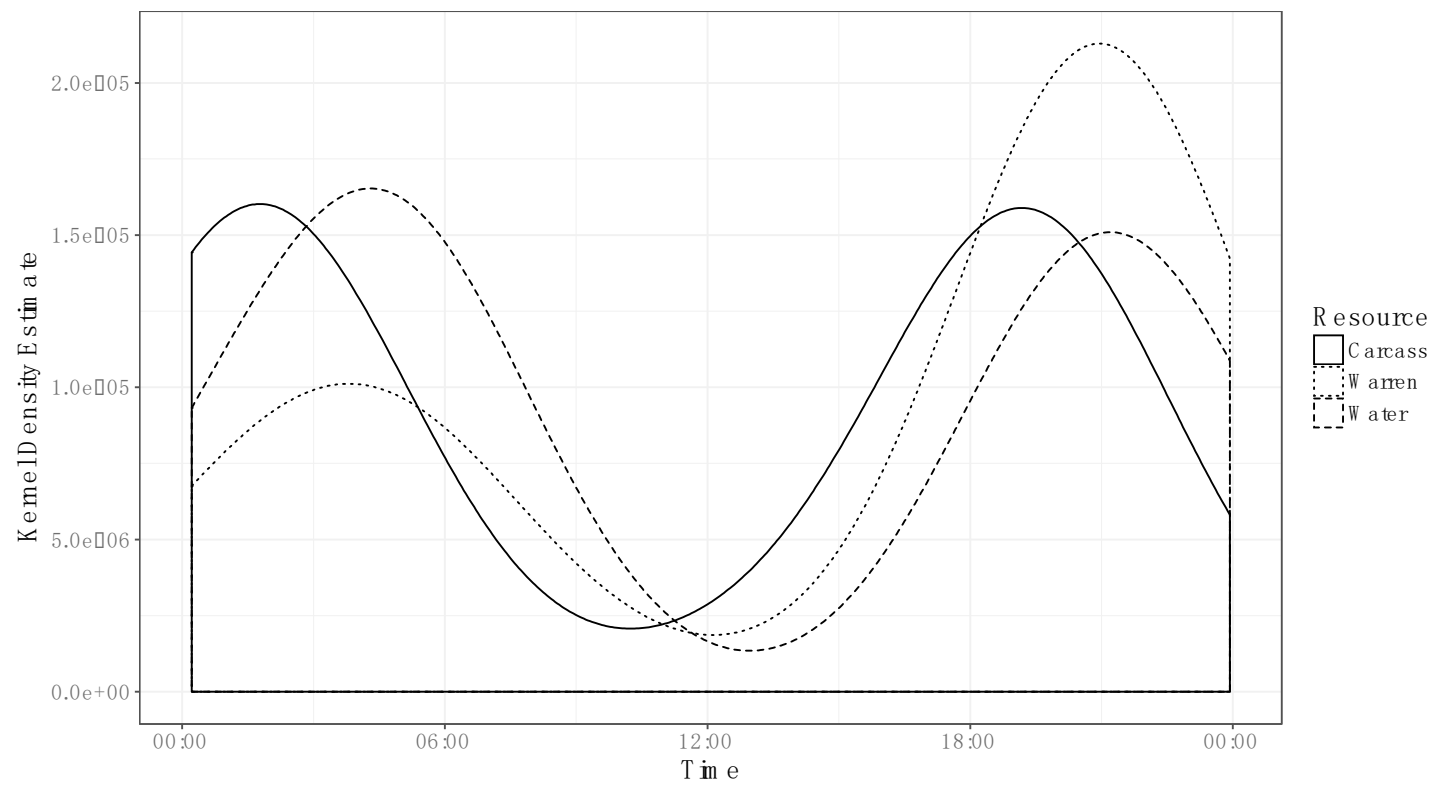

Figure 3. Fox temporal activity patterns at water points, rabbit warrens and carcasses gathered with camera traps in the Painted Desert, South Australia in the winters of 2016-2018. Solid line represents carcass temporal activity patterns, dashed line represents water points and dotted line represents rabbit warrens. Overlap coefficient between the three resource points is $56 \%$.

Table 4. Descriptive statistics of the time allocated to different behavioural states at the three resource points, depending upon whether the behaviours were expressed cautiously or confidently.

\begin{tabular}{cccccccc}
\hline & & Cautious & \multicolumn{3}{c}{ Confident } \\
\hline Resource & Behaviour & No. & Total Time & Average Time & No. & Total Time & Average Time \\
\hline Carcass & Digging & & 0 & N/A & 7 & 10.5 & 1.5 \\
& Foraging & 8 & 80.3 & 10.0 & 44 & 386.6 & 8.8 \\
& Investigating & 1 & 8.0 & 8.0 & 23 & 112.7 & 4.9 \\
& Locomotion & 8 & 66.4 & 8.3 & 60 & 191.8 & 3.2 \\
& Scent marking & & 0 & N/A & 13 & 16.2 & 1.2 \\
& Sniffing & 6 & 7.0 & 1.2 & 51 & 218.0 & 4.3 \\
& Vigilance & 30 & 108.3 & 3.6 & & 0 & N/A \\
Warren & Foraging & & 0 & N/A & 9 & 65.2 & 7.2 \\
& Investigating & 18 & 98.2 & 5.4 & 34 & 183.7 & 5.4 \\
& Locomotion & 26 & 89.3 & 3.4 & 67 & 160.2 & 2.4 \\
& Scent marking & & 0 & N/A & 2 & 2.1 & 1.0 \\
& Sniffing & 18 & 54.7 & 3.0 & 32 & 93.2 & 2.9 \\
& Vigilance & 28 & 101.7 & 3.6 & & 0 & N/A \\
& Digging & & 0 & N/A & 2 & 0 & 0 \\
& Foraging & 5 & 47.5 & 9.5 & 33 & 362.3 & 11.0 \\
& Investigating & 15 & 48.6 & 3.2 & 10 & 46.5 & 4.7 \\
& Locomotion & 42 & 131.1 & 3.1 & 99 & 316.0 & 3.2 \\
& Scent marking & & 0 & N/A & 16 & 25.0 & 1.6 \\
& Sniffing & 15 & 59.3 & 4.0 & 41 & 145.0 & 3.5 \\
& Vigilance & 55 & 236.7 & 4.3 & & 0 & N/A \\
& & 275 & 1137.1 & 4.1 & 543 & 2335.1 & 4.3 \\
\hline
\end{tabular}

Time is represented in seconds (s).

\section{Discussion}

Foxes were surprisingly confident at resource points shared with territorial dingo packs, when free from human persecution. We had hypothesised that the threat presented by socially stable dingoes would induce foxes, more often than not, to be "on their toes" when visiting these peaks in the landscape of fear. On the whole, we found that foxes were much more likely to express their 
behaviours in confident states while at resource points, suggesting that foxes are not living in a state of fear. However, the evidence of cautious behaviours exhibited by foxes at resource points exemplifies the suppressive effects of apex predators, and mirrors behaviours observed in other fox populations coexisting with apex predators around the world [16,55].

The behaviour of foxes may be influenced by both their own social stability and that of their predators. Social stability in apex predators is a key driver of ecosystem function and has significant ecological flow-on effects [6]. The protection of predators and the promotion of their social stability enables coexistence between predators [56]. Cheetahs (Acinonyx jubatus) and spotted hyenas (Crocuta crocuta) living in the protected areas of Serengeti National Park, Tanzania, coexist with lions (Panthera leo) through "moment-to-moment" temporal avoidance of the apex predator, suggesting that smaller predators have a developed understanding of the spatiotemporal activities of lions, and how to behave in order to avoid them [57]. We propose that when a population of apex predators is socially stable, sympatric mesopredators may also be increasingly bold due to the territorial stability of apex predators, [41] potentially reducing the risk involved with spatially avoiding predators.

Although foxes were more likely to be confident at carcasses, when foxes were locomoting cautiously they did it significantly longer than when they did it confidently. This suggests that when foxes perceive increased risk at carcasses, they alter their behaviour to reduce the threat of encountering a dingo. Cattle carcasses are a valuable resource in arid ecosystems and dingoes regularly feed upon them [58]. The high value of carcasses to dingoes, and the increased caution that foxes exhibit on occasion, may suggest that dingoes are increasingly territorial and defensive of carcasses over other resource points. We acknowledge our video data of fox behaviour over our three-year sampling period, is limited and should be interpreted as such.

Evidence for this is emphasised by dingoes' scent marking all of the carcasses surveyed, a behaviour that indicates ownership and territoriality in large canids [21,41]. In apparent 'disregard' for dingo territoriality, foxes regularly scent-marked resource points, including on large carcasses and water sources heavily marked and visited by dingoes. Similar observations of foxes marking existing apex predator scats have been observed in Poland, where foxes were observed inspecting scats of lynx and scent-marking over them [13]. Likewise, grey foxes (Urocyon cinereoargenteus) have been observed remarking the scent marks of pumas (Puma concolor) [59]. The functional benefits of re-marking scats of apex predators can only be speculated on, but it may serve to communicate to both conspecifics and predators. Further research is required to develop a deeper understanding of the role of over marking in the behavioural interactions involving apex- and meso-predators.

Observations of fox sociality in the wild are rare because foxes spend large amounts of time alone, however, we observed fox social behaviour at two carcasses. This may be attributed to our study being conducted in the winter, during their mating season [60]. Pair interactions were comprised of amicable play and greeting, suggesting the two were either paired or kin. Play behaviour between pairs at carcasses commonly frequented by dingoes provides further evidence that these foxes were generally at ease in this landscape.

The foxes in this study were most commonly observed at resource points between dusk and dawn, which is consistent with observations that foxes are nocturnal in their native range [35,36]. Temporal overlap between the three resource points was relatively low (56\%), suggesting that foxes may engage in routines in which they access different resource points at different times of the day.

Considering that dingoes have been shown to have strong suppressive effects on foxes $[6,11,15,19]$, why where these foxes much more likely to be confident than cautious around these shared resources? One possibility is that socially-stable apex predators are more predictable and therefore less frightening. Foxes may be able to identify, anticipate, and appropriately respond to the risk of dingo predation, therefore reducing the fear of unexpected attacks. Further research could help illuminate the role of social stability in shaping behavioural interactions between two of Australia's most prominent predators. 
Supplementary Materials: The following are available online at http://www.mdpi.com/2076-2615/9/11/907/s1, Table S1: Negative binomial model results of the proportion of time spent in each behaviour at different resource points.

Author Contributions: Conceptualisation, E.W., A.D.W. and D.R.; investigation, E.W. and A.D.W.; formal analysis, E.W. and D.R.; writing—original draft, E.W.; writing—review and editing, E.W., A.D.W. and D.R.; supervision, A.D.W. and D.R.; funding acquisition, A.D.W. and D.R.

Funding: This study was funded by Australian Research Council grant number DP180100272.

Acknowledgments: We are grateful to Charlie Jackson-Martin and Marc Bekoff for expert advice on fox behaviour. We thank Adam O'Neill and Erick Lundgren for assistance with field work and Steve Woodcock for assistance with calculating the overlap coefficient. We thank Caroline Thomas and John Knight for permission and hospitality at Evelyn Downs, and we thank the Lennon family, the traditional custodians of Mount Willoughby, for permission and hospitality.

Conflicts of Interest: The authors declare no conflict of interest.

\section{References}

1. Macdonald, D.W.; Reynolds, J. Red Fox (Vulpes vulpes). Canids: Foxes, Wolves, Jackals, and Dogs. In Status Survey and Conservation Action Plan; Sillero-Zubiri, C., Hoffmann, M., Macdonald, D.W., Eds.; IUCN: Gland, Switzerland; Cambridge, UK, 2004; pp. 129-135.

2. Contesse, P.; Hegglin, D.; Gloor, S.; Bontadina, F.; Deplazes, P. The diet of urban foxes (Vulpes vulpes) and the availability of anthropogenic food in the city of Zurich, Switzerland. Mamm. Biol. 2004, 69, 81-95. [CrossRef]

3. Prugh, L.R.; Stoner, C.J.; Epps, C.W.; Bean, W.T.; Ripple, W.J.; Laliberte, A.S.; Brashares, J.S. The rise of the mesopredator. Bioscience 2009, 59, 779-791. [CrossRef]

4. Long, J.L. Introduced Mammals of the World: Their History, Distribution and Influence; CSIRO Publishing: Clayton, Australia, 2003; pp. 239-242.

5. Dickman, C.R. Impact of exotic generalist predators on the native fauna of Australia. Wildl. Biol. 1996, 2, 185-195. [CrossRef]

6. Wallach, A.D.; Johnson, C.N.; Ritchie, E.G.; O'Neill, A.J. Predator control promotes invasive dominated ecological states. Ecol. Lett. 2010, 13, 1008-1018. [CrossRef]

7. Haswell, P.M.; Kusak, J.; Hayward, M.W. Large carnivore impacts are context-dependent. Food Webs 2017, 12, 3-13. [CrossRef]

8. Cupples, J.B.; Crowther, M.S.; Story, G.; Letnic, M. Dietary overlap and prey selectivity among sympatric carnivores: Could dingoes suppress foxes through competition for prey? J. Mammal. 2011, 92, 590-600. [CrossRef]

9. Mueller, M.A.; Drake, D.; Allen, A.J. Coexistence of coyotes (Canis latrans) and red foxes (Vulpes vulpes) in an urban landscape. PLoS ONE 2018, 13, e0190971. [CrossRef]

10. Newsome, T.M.; Greenville, A.C.; Cirovic, D.; Dickman, C.R.; Johnson, C.N.; Krofel, M.; Letnic, M.; Ripple, W.J.; Ritchie, E.G.; Stoyanov, S.; et al. Top predators constrain mesopredator distributions. Nat. Commun. 2017, 8, 15469. [CrossRef]

11. Letnic, M.; Greenville, A.C.; Denny, E.; Dickman, C.R.; Tischler, M.; Gordon, C.; Koch, F. Does a top predator suppress the abundance of an invasive mesopredator at a continental scale? Glob. Ecol. Biogeogr. 2011, 20, 343-353. [CrossRef]

12. Scheinin, S.; Yom-Tov, Y.; Motro, U.; Geffen, E. Behavioural responses of red foxes to an increase in the presence of golden jackals: A field experiment. Anim. Behav. 2006, 71, 577-584. [CrossRef]

13. Wikenros, C.; Jarnemo, A.; Frisen, M.; Kuijper, D.P.J.; Schmidt, K. Mesopredator behavioural response to olfactory signals of an apex predator. J. Ethol. 2017, 35, 161-168. [CrossRef] [PubMed]

14. Laundre, J.W.; Hernandez, L.; Ripple, W.J. The landscape of fear: Ecological implications of being afraid. Open Ecol. J. 2009, 3, 1-7. [CrossRef]

15. Brawata, R.L.; Neeman, T. Is water the key? Dingo management, intraguild interactions and predator distribution around water points in arid Australia. Wildl. Res. 2011, 38, 426-436. [CrossRef]

16. Haswell, P.M.; Jones, K.A.; Kusak, J.; Hayward, M.W. Fear, foraging and olfaction: How mesopredators avoid costly interactions with apex predators. Oecologia 2018, 187, 573-583. [CrossRef] [PubMed]

17. Harding, E.; Doak, D.; Albertson, D. Evaluating the effectiveness of predator control - the non-native red fox as a case study. Conserv. Biol. 2001, 15, 114-1122. [CrossRef] 
18. Mahon, P.S. Targeted control of widespread exotic species for biodiversity conservation: The red fox (Vulpes vulpes) in New South Wales, Australia. Ecol. Manag. Restor. 2009, 10, 59-69. [CrossRef]

19. Leo, V.; Reading, R.P.; Letnic, M. Interference competition: Odours of an apex predator and conspecifics influence resource acquisition by red foxes. Oecologia 2015, 179, 1033-1040. [CrossRef]

20. Voigt, D.R.; Earle, B.D. Avoidance of coyotes by red fox families. J. Wildl. Manag. 1983, 47, 852-857. [CrossRef]

21. Meyer, S.; Weber, J.M. Ontogeny of dominance in free-living red foxes. Ethology 1996, 102, 1008-1019. [CrossRef]

22. Zabel, C.J.; Taggart, S.J. Shift in red fox (Vulpes vulpes) mating system associated with El Niño in the Bering Sea. Anim. Behav. 1989, 38, 830-838. [CrossRef]

23. Baker, P.J.; Robertson, C.P.J.; Funk, S.M.; Harris, S. Potential fitness benefits of group living in the red fox (Vulpes vulpes). Anim. Behav. 1998, 56, 1411-1424. [CrossRef] [PubMed]

24. Blizard, R.A.; Perry, G.C. Response of captive male red foxes (Vulpes vulpes) to some conspecific odors. J. Chem. Ecol. 1979, 5, 869-880. [CrossRef]

25. Fox, M. Behaviour of Wolves Dogs and Related Canids; Dogwise Publishing: New York, NY, USA, 1971.

26. Henry, J.D. The use of urine marking in the scavenging behaviour of the red fox (Vulpes vulpes). Behaviour 1977, 61, 82-105. [CrossRef]

27. Macdonald, D.W. Some observations and field experiments on the urine marking behaviour of the red fox (Vulpes vulpes). Z. Tierpsychol. 1979, 51, 1-22. [CrossRef]

28. Monclús, R.; Arroyo, M.; Valencia, A.; de Miguel, F.J. Red foxes (Vulpes vulpes) use rabbit (Oryctolagus cuniculus) scent marks as territorial marking sites. J. Ethol. 2009, 27, 153-156. [CrossRef]

29. Baker, P.J.; Dowding, C.V.; Molony, S.E.; White, P.C.L.; Harris, S. Activity patterns of urban red foxes (Vulpes vulpes) reduce the risk of traffic-induced mortality. Behav. Ecol. 2007, 18, 716-734. [CrossRef]

30. Soulsbury, C.D.; Iossa, G.; Baker, P.J.; White, P.C.L.; Harris, S. Behavioural and spatial analysis of extraterritorial movements in red foxes (Vulpes vulpes). J. Mammal. 2011, 92, 190-199. [CrossRef]

31. Tolhurst, B.A.; Grogan, H.; Hughes, H. Effects of temporary captivity on ranging behaviour in urban red foxes (Vulpes vulpes). Appl. Anim. Behav. Sci. 2016, 181, 182-190. [CrossRef]

32. Iossa, G.; Soulsbury, C.D.; Baker, P.J.; Edwards, K.J.; Harris, S. Behavioural changes associated with a population density decline in the facultatively social red fox. Behav. Ecol. 2009, 20, 385-395. [CrossRef]

33. Cagnacci, F.; Meriggi, A.; Lovari, S. Habitat selection by the red fox (Vulpes vulpes) in an Alpine area. Ethology, Ecol. Evol. 2004, 16, 103-116. [CrossRef]

34. Cavallini, P.; Lovari, S. Environmental factors influencing the use of habitat in the red fox (Vulpes vulpes). J. Zool. 1991, 223, 323-339. [CrossRef]

35. Lucherini, M.; Lovari, S.; Crema, G. Habitat use and ranging behaviour of the red fox (Vulpes vulpes) in a Mediterranean rural area: Is shelter availability a key factor? J. Zool. 1995, 237, 577-591. [CrossRef]

36. Cavallini, P. Ranging behaviour of the red fox (Vulpes vulpes) in rural southern Japan. J. Mammal. 1992, 73, 321-325. [CrossRef]

37. Kistler, C.; Hegglin, D.; Würbel, H.; König, B. Feeding enrichment in an opportunistic carnivore: The red fox. Appl. Anim. Behav. Sci. 2009, 116, 260-265. [CrossRef]

38. Jarnemo, A. Predation processes: Behavioural interactions between red fox and roe deer during the fawning season. J. Ethol. 2004, 22. [CrossRef]

39. Saunders, G.; Coman, B.; Kinnear, J.; Braysher, M. Managing Vertebrate Pests: Foxes; Australian Government Publishing Service: Canberra, Australia, 1995.

40. Wallach, A.D.; Ramp, D.; O’Neill, A.J. Cattle mortality on a predator-friendly station in central Australia. J. Mammal. 2017, 98, 45-52. [CrossRef]

41. Wallach, A.D.; Ritchie, E.G.; Read, J.; O'Neill, A.J. More than mere numbers: The impact of lethal control on the social stability of a top-order predator. PLoS ONE 2009, 4, e6861. [CrossRef]

42. Moseby, K.E.; Stott, J.; Crisp, H. Movement patterns of feral predators in an arid environment-implications for control through poison baiting. Wildl. Res. 2009, 36, 422-435. [CrossRef]

43. Destefano, S.; Schmidt, S.L.; DeVos, C.J. Observations of predator activity at wildlife water developments in southern Arizona. J. Range Manag. 2000, 53, 255-258. [CrossRef]

44. Mitchell, B.D.; Banks, P.B. Do wild dogs exclude foxes? Evidence for competition from dietary and spatial overlaps. Austral Ecol. 2005, 30, 581-591. [CrossRef]

45. Coman, B.J. The diet of red foxes (Vulpes vulpes) in Victoria. Aust. J. Zool. 1973, 21, 391-401. [CrossRef] 
46. Glen, A.S.; Dickman, C.R.; Soulé, M.E.; Mackey, B.G. Evaluating the role of the dingo as a trophic regulator in Australian ecosystems. Austral Ecol. 2007, 32, 492-501. [CrossRef]

47. Torretta, E.; Serafini, M.; Puopolo, F.; Schenone, L. Spatial and temporal adjustments allowing the coexistence among carnivores in Liguria (NW Italy). Acta Ethol. 2016, 19, 123-132. [CrossRef]

48. Way, J.G.; Szumylo, D.L.M.; Strauss, E.G. An ethogram developed on captive eastern coyotes Canis Latrans. Can. Field-Nat. 2006, 120, 263-288. [CrossRef]

49. MacNulty, D.R.; Mech, L.D.; Smith, D.W. A proposed ethogram of large-carnivore predatory behaviour, exemplified by the wolf. J. Mammal. 2007, 88, 595-605. [CrossRef]

50. Ghaskadbi, P.; Habib, B.; Qureshi, Q. A whistle in the woods: An ethogram and activity budget for the dhole in central India. J. Mammal. 2016, 97, 1745-1752. [CrossRef]

51. Biro, P.A.; Stamps, J.A. Are animal personality traits linked to life-history productivity? Trends Ecol. Evol. 2008, 23, 361-368. [CrossRef]

52. Mellor, D.J.; Beausoleil, N.J. Extending the 'Five Domains' model for animal welfare assessment to incorporate positive welfare states. Anim. Welf. 2015, 24, 241-253. [CrossRef]

53. Friard, O.; Gamba, M. BORIS: A free, versatile open-source event-logging software for video/audio coding and live observations. Methods Ecol. Evol. 2016, 7, 1325-1330. [CrossRef]

54. R Core Team. R: A Language and Environment for Statistical Computing; R Foundation for Statistical Computing: Vienna, Austria, 2010.

55. Wikenros, C.; Ståhlberg, S.; Sand, H. Feeding under high risk of intraguild predation: Vigilance patterns of two medium-sized generalist predators. J. Mammal. 2014, 95, 862-870. [CrossRef]

56. Wallach, A.D.; Ripple, W.J.; Carroll, S.P. Novel trophic cascades: Apex predators enable coexistence. Trends Ecol. Evol. 2015, 30, 146-153. [CrossRef] [PubMed]

57. Swanson, A.; Arnold, T.; Kosmala, M.; Forester, J.; Packer, C. In the absence of a "landscape of fear": How lions, hyenas, and cheetahs coexist. Ecol. Evol. 2016, 6, 8534-8545. [CrossRef] [PubMed]

58. Corbett, L.K.; Newsome, A.E. The feeding ecology of the dingo. Oecologia 1987, 74, 215-227. [CrossRef] [PubMed]

59. Allen, M.L.; Gunther, M.S.; Wilmers, C.C. The scent of your enemy is my friend? The acquisition of large carnivore scent by a smaller carnivore. J. Ethol. 2016, 35, 13-19. [CrossRef]

60. McIntosh, D. Reproduction and growth of the fox in the Canberra district. Wildl. Res. 1963, 8, $132-141$. [CrossRef]

(C) 2019 by the authors. Licensee MDPI, Basel, Switzerland. This article is an open access article distributed under the terms and conditions of the Creative Commons Attribution (CC BY) license (http://creativecommons.org/licenses/by/4.0/). 